\title{
Mcm2 and Mcm3, two proteins important for ARS activity, are related in structure and function
}

\author{
Hong Yan, Susan Gibson, ${ }^{1}$ and Bik K. Tye \\ Section of Biochemistry, Molecular and Cell Biology, Cornell University, Ithaca, New York 14853 USA
}

\begin{abstract}
MCM2 and MCM3 are essential genes believed to play important roles in the initiation of DNA replication in Saccharomyces cerevisiae. Mutants defective in $M \mathrm{~cm} 2$ or $\mathrm{Mcm} 3$ are remarkably similar in phenotype. They both show an autonomously replicating sequence (ARS)-specific minichromosome maintenance defect, although their ARS specificities are not identical. In addition, these mutants exhibit a premitotic cell cycle arrest and an increase in chromosome loss and recombination. Genetic studies suggest that the two $M C M$ gene products play interacting or complementary roles in DNA replication. Double mutants of mcm2-1 and mcm3-1 are inviable at the permissive growth temperature $\left(23^{\circ} \mathrm{C}\right)$ for each of the single mutants. Furthermore, overproduction of $\mathrm{Mcm} 3$ accentuates the deleterious effect of the $\mathrm{mcm} 2-1$ mutation, whereas overproduction of $M c m 2$ partially complements the $m c m 3-1$ mutation. MCM2 encodes a protein of 890 amino acids containing a putative zinc-finger domain that is essential for Mcm2 function. Mcm2 shows striking homology to $M \mathrm{~cm} 3$ and three other proteins, Cdc46 of S. cerevisiae, and Nda4 and Cdc21 of Schizosaccharomyces pombe. The phenotypes of mutants defective in these proteins suggest that they belong to a protein family involved in the early steps of DNA replication.
\end{abstract}

[Key Words: MCM2; MCM3; DNA replication; Saccharomyces cerevisiae; ARS]

Received February 7, 1991; accepted March 12, 1991.

The initiation of DNA replication at replication origins is a complex process involving the concerted action of many proteins. In Escherichia coli, this sequence of events is carried out by a number of proteins including dnaA, which binds and melts the origin region, and the primosome, which unwinds and initiates DNA synthesis (Bramhill and Kornberg 1988). In SV40, the virally encoded $\mathrm{T}$ antigen plays an analogous role to the dnaA protein in the binding and melting of the origin region (Stillman 1989). The mechanism for the initiation of DNA replication of eukaryotic genomes, which involves initiation at a large number of sites, may be more complex. Even the small genome of the yeast Saccharomyces cerevisiae contains at least 250 replication origins (Chan and Tye 1980). The complexity of the enzyme system committed to these initiation events at multiple sites is unknown.

The autonomously replicating sequences (ARSs), which serve as chromosomal replication origins in yeast (Huberman et al. 1988), are AT-rich sequences that contain an 11-bp consensus sequence (Broach et al. 1983). This consensus sequence is essential but not sufficient for ARS function, requiring the presence of flanking sequences that have little in common. To explain how

${ }^{1}$ Present address: MSU-DOE Plant Research Laboratory, Michigan State University, East Lansing, MI 48824 USA. these seemingly dissimilar flanking sequences might provide similar auxiliary function in different ARSs, it has been suggested that the AT content and, therefore, the local melting properties of the flanking sequences, determine the functionality of an ARS /Umek and Kowalski 1988). Alternatively, the melting of flanking sequences could be facilitated by initiator proteins that bind specifically to these sequences. Interestingly, two ARS-binding proteins, ABFl (Diffley and Stillman 1988), identified by its affinity to ARS1, and OBF1 (Eisenberg et al. 1988), identified by its affinity to ARS121, which were first thought to be different proteins based on their affinities to apparently unrelated sequences, turned out to be the same protein with broad binding specificity (Biswas and Biswas 1990). This finding suggests that if ABF1-OBFl plays the role of an enhancer of DNA replication (Walker et al. 1990), it does so by acting at a large number of ARSs.

Parallel to the studies on ARS-binding proteins, we attempted to identify gene products involved in DNA replication initiation by isolating mutants that fail to activate ARSs. Analysis of the effect of these mutants on a spectrum of ARSs should allow us to determine whether a particular gene product is required for the initiation of DNA replication at all ARSs, at some subset of ARSs, or at only one ARS. Previously, we have identified a number of mutants defective in the maintenance of 
minichromosomes (Maine et al. 1984). Mutants in five complementation groups were of particular interest because, based on plasmid stability assays, they affected the function of all ARSs tested, but each to a different extent (Gibson et al. 1987). This phenotype of these $\mathrm{mcm}$ mutants suggests that their gene products are involved in the initiation of DNA replication at ARSs, rather than in other aspects of replication or segregation. In fact, we have confirmed that one of these mutants, $m \mathrm{~cm} 2$, affects the replication, rather than the segregation, of plasmids (Sinha et al. 1986). We have carried out detailed analyses on three of the ARS-specific mutants, $m c m 1, m c m 2$, and $m c m 3$, that were isolated in three independent mutant screens, each involving a minichromosome carrying a different ARS (Maine et al. 1984; Sinha et al. 1986; Gibson et al. 1990). Mutations in all of these genes also cause other phenotypes that are characteristic of defects in DNA replication, such as premitotic cell cycle arrest and increased chromosome loss and recombination; this suggests that these gene products may play similar roles in replication initiation at ARSs. $\mathrm{Mcml}$ is a multifunctional protein that plays important roles in transcriptional regulation in addition to ARS function (Passmore et al. 1988, 1989). In this discussion we examine the structural and functional relationships between the MCM2 and MCM3 gene products. We show that $\mathrm{Mcm} 2$ and $\mathrm{Mcm} 3$ belong to a family of proteins that are likely to be involved in the early steps of DNA replication.

\section{Results \\ Cloning and mapping of the MCM2 gene}

The mcm2-1 mutation, although not lethal to the cell, results in a slower growth rate at $37^{\circ} \mathrm{C}$. Furthermore, at this temperature, minichromosomes containing ARS1 are extremely unstable, being lost at a rate of $\sim 0.5 /$ cell per generation. Thus, an $m c m 2-1$ mutant that relies on $A R S 1$-containing plasmids to complement its auxotrophic deficiencies grows extremely poorly on selective medium at $37^{\circ} \mathrm{C}$. We cloned the MCM2 gene by complementation of this poor growth phenotype.

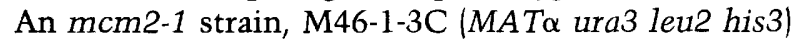
was transformed to uracil prototrophy using a library of yeast DNA cloned in the vector YCp50 (ARS1 CEN4 URA3) (Rose et al. 1987) and to leucine prototrophy using the plasmid YCp101 (ARS1 CEN5 LEU2). The transformed culture was plated on complete medium lacking uracil and leucine, grown for $2.5 \mathrm{hr}$ at $23^{\circ} \mathrm{C}$ and for an additional $70 \mathrm{hr}$ at $37^{\circ} \mathrm{C}$. Transformants containing a wild-type copy of the MCM2 gene will stabilize both plasmids and can be identified by their large colony size. From $\sim 30,000$ transformants, 37 gave rise to large colonies and were identified as possibly containing the wildtype $M C M 2$ gene.

One such transformant, M46-33, was chosen for further study. Stability assays indicate that this transformant maintains minichromosomes at wild-type or almost wild-type levels (Table 1). In addition, its growth defect at $37^{\circ} \mathrm{C}$ is no longer apparent (data not shown).
Table 1. Minichromosome stability at $35^{\circ} \mathrm{C}$ in $\mathrm{mcm} 2-1$ strain transformed with plasmid [pM46-33] carrying the putative MCM2 gene

\begin{tabular}{lrl}
\hline Strain (genotype) & $\begin{array}{c}\text { Stability } \\
(\%)^{\mathrm{a}}\end{array}$ & Minichromosome \\
\hline $\mathrm{M} 46-1-3 \mathrm{C}(\mathrm{mcm} 2-1)$ & 0 & YCp101 (ARS1 CEN5 LEU2) \\
$8534-8 \mathrm{C}(M C M 2)$ & 71 & YCp101 (ARS1 CEN5 LEU2) \\
$\mathrm{MY4C/Y4}(\mathrm{mcm} 2-1 / M C M 2)$ & 29 & pYES3 (ARS1 CEN5 URA3) \\
M46-1-3C [pM46-33] & 55 & YCp101 (ARS1 CEN5 LEU2) \\
\hline a Stability is the final percentage of cells still carrying the test \\
plasmid after 10 generations of growth in nonselective medium \\
at $35^{\circ} \mathrm{C}$.
\end{tabular}

When the plasmid was isolated and retransformed into another $m \mathrm{~cm} 2-1$ strain, the strain became $\mathrm{Mcm}^{+}$in phenotype. Furthermore, we showed that the chromosomal location of the cloned yeast DNA insert is tightly linked to the $m c m 2-1$ mutation. This was achieved by targeting integration of the URA3 gene into the chromosomal location of the cloned yeast DNA insert in an mcm2-1 mutant strain. A transformant, designated tAM46-1-3C, was then crossed with the wild-type strain TD4. The diploid was sporulated, and the $M \mathrm{~cm} 2$ and Ura3 phenotypes of the resultant spores were analyzed. The $\mathrm{Mcm} 2^{-}$and $\mathrm{Ura}^{+}$phenotypes cosegregated in all 13 tetrads examined, suggesting that the chromosomal location of the yeast DNA insert is either very close to, or the same as, that of the mcm2-1 mutation. These results indicate that the cloned yeast DNA insert contains the MCM2 gene.

We further localized the MCM2 gene within the 10-kb cloned fragment by transposon mutagenesis (see Materials and methods). As shown in Figure 1a, transposons at positions $6,20,31,52$, and 135 destroyed, whereas transposons at positions $1,12,14,19,21,32,108$, and 134 preserved the ability of the clone to complement the mcm2-1 mutation. Therefore, the MCM2 gene must reside in the region indicated by hatching. A $3.5-\mathrm{kb}$ subclone containing this region (from BglII to the second ClaI; Fig. la and $\mathrm{b}$ ) is fully capable of complementing the mcm2-1 mutation (data not shown).

We also showed that MCM2 is located on chromosome II by hybridizing part of the MCM2 gene to a chromosome blot (kindly supplied by Dr. H. Klein). Tetrad analysis placed MCM2 between pet 9 and $A M Y 2$ on the left arm of chromosome II (Gibson 1989).

\section{MCM2 is essential for cell viability}

To investigate whether MCM2 is essential for growth, we constructed a diploid strain with one of the copies of MCM2 disrupted by gene replacement (Rothstein 1983). The disrupted copy contained the URA3 gene as part of the minitransposon Tn 3 at position 135 (see Fig. la). This diploid was sporulated, and tetrads were dissected. Of the 20 tetrads analyzed, 18 yielded two viable spores and 2 yielded one viable spore. Furthermore, all viable spores were $\mathrm{Ura}^{-}$, indicating that they have the wild- 


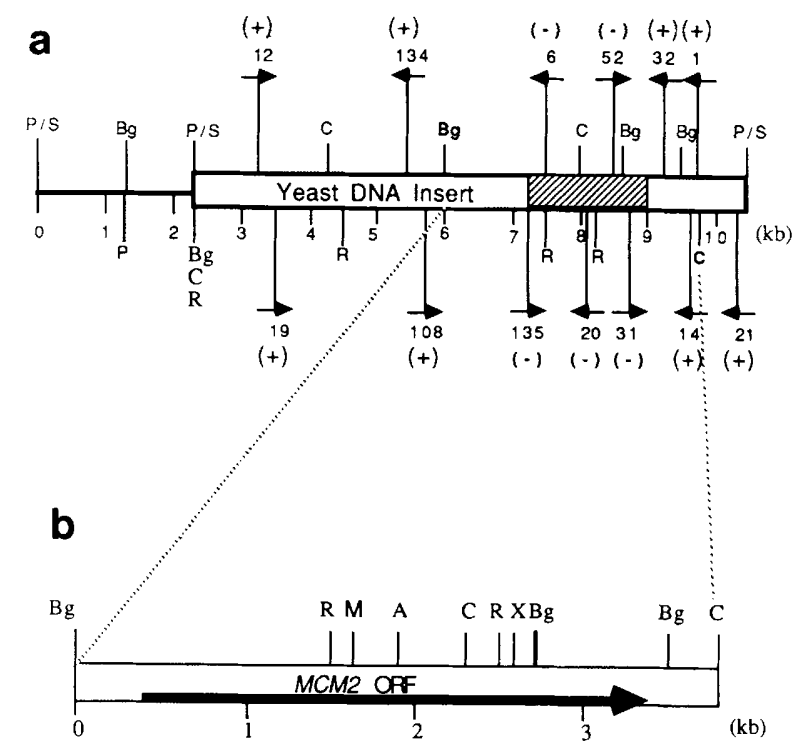

Figure 1. (a) Localization of the MCM2 gene within the original clone by minitransposon mutagenesis. Numbers and arrows indicate the positions and orientations of the transposons. I+ and -1 Complementation and no complementation, respectively, of the temperature-sensitive growth phenotype of mcm2-1 mutant cells at $37^{\circ} \mathrm{C}$. Hatched region indicates the location of the MCM2 gene. (b) Restriction map of the BglII-ClaI fragment containing the MCM2 gene. The arrow indicates the $\mathrm{ORF}$ and its orientation. (A) $A p a \mathrm{I} ;(\mathrm{Bg}) B g l \mathrm{II}$; (C) CIaI; (M) MluI; (P) PvuII; (R) EcoRI; (S) SmaI (X) XbaI.

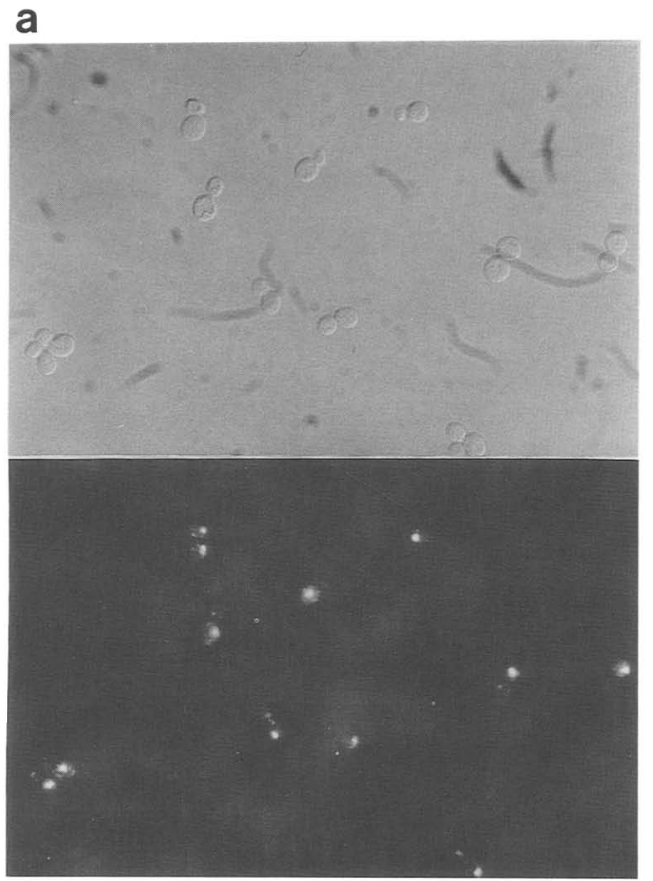

type copy of the MCM2 gene. Examination of the dead spores indicated that they arrested after two or three cell divisions with a dumbbell morphology. This result suggests that $\mathrm{Mcm} 2$ is essential for cell-division cycle.

\section{Depletion of $M c m 2$ results in cell cycle arrest at the end of $S$ phase}

The arrest phenotype of the $m c m 2$ disruption mutant led us to further characterize the phenotype of cells depleted in $\mathrm{Mcm} 2$. Because we do not have a tight temperaturesensitive mutant allele of $m \mathrm{~cm} 2$, we constructed a conditionally expressed $\mathrm{mcm} 2$ allele. The $M C M 2$ open reading frame (ORF) was placed downstream of the galactoseinducible $G A L 1$ promoter in the plasmid $\mathrm{pHY} 12$. This plasmid complements the mcm2::LEU2 disruption in the yeast strain HY101d; therefore, it has a growth rate similar to its parent strain TD4 on galactose medium. Upon shift to glucose medium, however, it stops growing within $6-8 \mathrm{hr}$, with $>95 \%$ of the cells arresting at the large bud stage (Fig. 2a). When arrested cells were stained with 4,6-diamidino-2-phenolindole (DAPI), a DNA-specific fluorescent dye, $>90 \%$ of the cells contained a single nucleus that is not generally localized at the bud neck (Fig 2b).

We also carried out flow cytometric analysis to determine the DNA content of the Mcm2-depleted cells (Hutter and Eipel 1978). Cells growing in galactose medium were distributed in two major populations by DNA content with $39 \%$ of the cells having $\ln$ DNA and $54 \%$ of

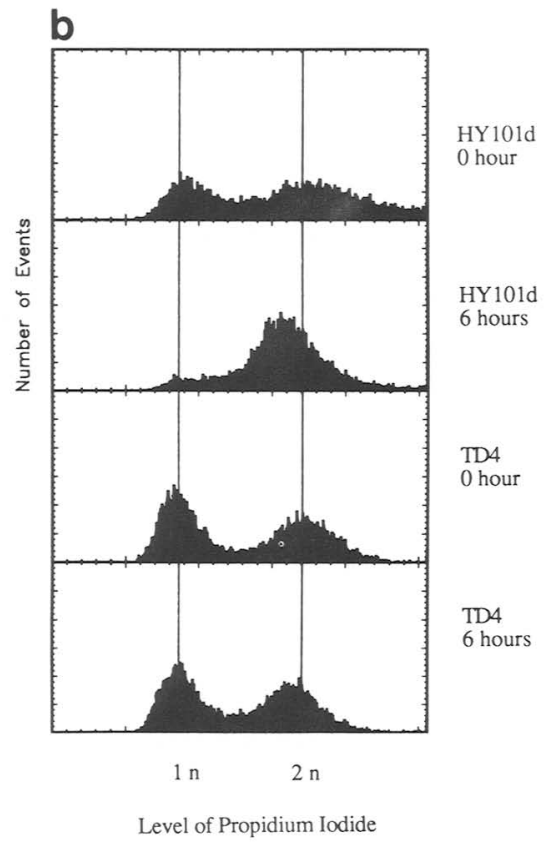

Figure 2. Arrest phenotype of Mcm2-depleted cells. Strain HY101d (mcm2::LEU2) carrying plasmid pHY12 (GAL1::MCM2) and wild-type strain TD4 were grown at $30^{\circ} \mathrm{C}$ to early log phase in complete galactose medium and then switched to complete glucose medium. Samples were taken at 0 or $6 \mathrm{hr}$ after shift and then stained with either DAPI or propidium iodide. $(a)$ DAPI-stained HY101d cells $6 \mathrm{hr}$ after shift to glucose medium. (Top) Phase-contrast field; (Bottom) fluorescence field. (b) Propidium iodide-stained cells analyzed by flow cytometry. The total cellular DNA content is proportional to the level of propidium iodide (in arbitrary units). 
the cells having 2n DNA (Fig. 2b; HY10ld, 0 hr). In contrast, $6 \mathrm{hr}$ after shift to glucose medium, $>85 \%$ of the cells contained close to 2n DNA (Fig. 2b; HY101d, $6 \mathrm{hr}$ ). However, the peak of this population of cells clearly falls below the 2n DNA content, suggesting that these cells have replicated most, but not all, of their DNA. No further significant change was observed in the distribution of fluorescence in the cell population $12 \mathrm{hr}$ after shift to glucose medium. Similar analysis of wild-type (TD4) cells indicated that changing the carbon source in the growth medium did not affect the DNA content distribution in the population. Minor differences in DNA content distribution between HY101d $139 \%$ in $1 \mathrm{n}, 54 \%$ in $2 n$ ) and TD4 (48\% in $1 n, 46 \%$ in $2 n$ ) growing in galactose may be attributed to the loss of pHY 12 in a small fraction of the cells and/or the effects of overproduction of $\mathrm{Mcm} 2$ in HY10ld.

\section{Mcm2 shows striking homology to $\mathrm{Mcm} 3$}

The nucleotide sequence of the MCM2 gene was deter- mined using the dideoxynucleotide chain-termination method (Sanger et al. 1977) and is available through EMBL data bank (accession number X53539). A long open-reading frame was found within the region corresponding to the $M C M 2$ gene. This sequence predicts a protein of 890 amino acids assuming that translation begins at the first ATG (Fig 3, upper sequence). When the GAL1 promoter was placed upstream of the first ATG of the MCM2 gene, an $\mathrm{Mcm} 2$ protein that complemented an $\mathrm{mcm} 2$ disruption was produced on galactose medium but not on glucose medium, indicating that this ORF indeed encodes $\mathrm{Mcm} 2$ (see above section). The predicted molecular weight of $\mathrm{Mcm} 2$ is 101,351 with a pI value of 6.4 .

A search through several sequence banks (GenBank, EMBL, NBRF, and SWISS PROT) failed to identify any known proteins with significant sequence similarity to Mcm2. However, a direct comparison between the ORFs of the three $M C M$ genes sequenced in our laboratory uncovered a striking homology between the Mcm2 and

Mcm2 1 MSDNRRRRREEDDSDSENELPPSSPQQHERGGMNPVSSP IGGPDMINFEGLDNEVDDVED LDF.VEFEMNEVD LMDDNMYYDYAADHNRDRYDPIDQVDDRE 100

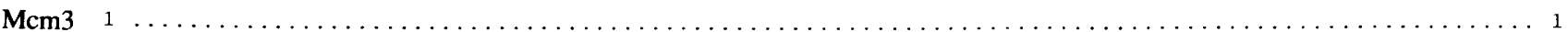

101 QQELSLSERRRIDAQLNERDRLLRNVAY IDDEDEEQEGAAQLDEMGLPVQRRRRRRQYEDLENTDDDLLSDIHIDPLREELTLESLSNVKANSYSEWITQ 200

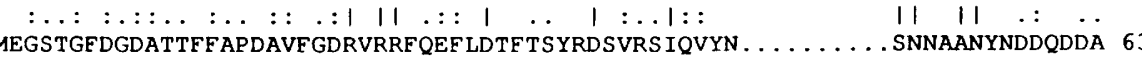

201 PNVSRT IARE LKSFLLEYTDETGRSVYGARIRTLGEMNSESLEVNYRHLAESKAILALFLAKCPEEMLKIFDLVAMEATELHYPDYARIHSE IHVRISDF 300

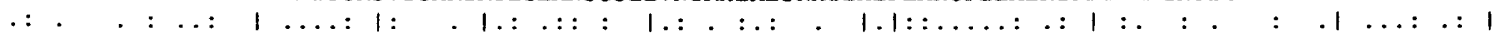
64 DERDLLGDDGDDLEKEKKAASSTSLNILPHRI I ISLD DLREFDRSFWSGILVEPAYF IPPAEKALTDLADSMDDVPHPNASAVSSRHPWKLSFKGSFG 162

301 PTIYSLRELRESNLSSLVRRTGVVTRRTGVFPQLKYVKFNCLKCGSILGPEFODSNEEI_.....RISFCTNOKSKGPFRVNGEKTVYRNYQRVTLQEAP 394 $: .11 .1 .1 \ldots 11 . .1: 11: .11 .1 \quad$. $1.1 .:$. $: 1 \ldots:$. . $: .1: \ldots \ldots: .:: \ldots: .11: 1: 111$

163 AHALSPRTLTAQHLNKLVSVEGIVTKTSLVRPKLIRSVHYAAKTGRFHYRDYTDATTTLTTR IPTPAIYPTEDTEGNKLTTEYGYSTF IDHQRITVQEMP 262

395 GTVPPGRLPRHREVILLADLVDVSKPGEEVEVTGIYKNNYDGNLNAKNG. .FPVFATI IEANS IKRREGNTANEGEEGLDVFSWTEEEEREFRKISRDRG 492

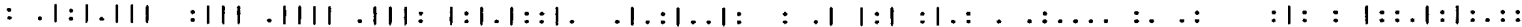

263 EMAPAGQLPRS IDVILDDDLVDKTKPGDRVNVVGVFKSLGAGGMNQSNSNTLIGFKTLILGNTVYPLHARSTGVAARQM . . . LTDFDIRNINKLSKKKD 358

493 IIDKIISSMAPSIYGHRD IKTAVACSLFGGVPKNVNPKHS IRGDINVLLLGDPGTAKSOILKYVEKTAHRAVFATGOGASAVGLTRSVRKHP ITKEWTLE 592

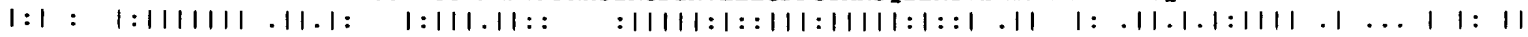

359 IFD ILSOSLAP S IYGHDH IKKAILLMLMGGVEKNLENGSHLRGD INI IMMVGD ST AKSQLLRFVLNTASLAIATTGRGSSGVGLTAAVTTDRETGERRLE 458

593 GGALVLADKGVCLIDEFDKMNDQDRTS IHEAMEQQS IS ISKAGIVTTLQARCS I I AAANPNGGRYNSTLP LAQNVSLTEP ILSRFDILCVVRDLVDEEAD 692

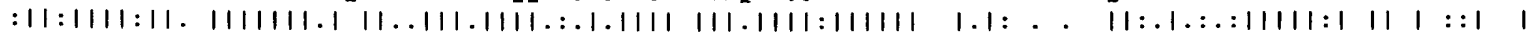

459 AGAMVLADRGVVCIDEFDKMTDVDRVA IHEVMEQQTVT IAKAGIHTTLNARCSVIAAANPVFGQYDVNRDP HONIALPDSLLSRFDLLFVVTDDINE IRD 558

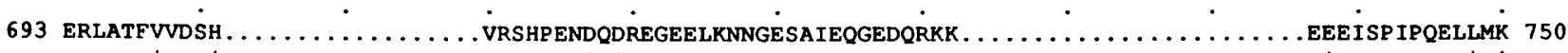

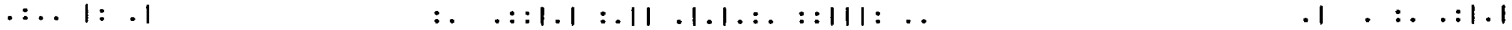

559 RSISEHVLRTHRYLPPGYLEGEPVRERLNLSLAVGEDAD INPEEHSNSGAGVENEGEDDEDHVFEKFNPLLQAGAKLAKNKGNYNGTEIPKLVTIPFLRK 658

751 YIHYARTKI YPKLHQMDMDKVSRVYADLRRESISTGSFP ITVRHLESILRIAESFAKMRLSEFVSSYDLDRAIKVVVDSFVDAQKVS ........ 837

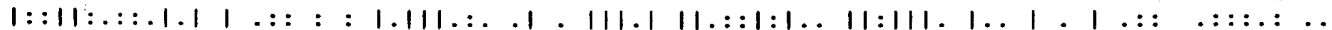

659 YVQYAKERVIPQLTQEAINVIVKNYTDLRND. NTKKSP ITARTLETLIRLATAHAKVRLSKTVNKVDAKVAANLLRFALLGEDIGNDIDEEESEYEEAL 757

838 VRRQLRSLSQFIPWVTKTLLFLRISGYEDKKFSVSIHVLAILFSIYKFPLFFVZ $\ldots \ldots \ldots \ldots \ldots \ldots \ldots \ldots \ldots \ldots$ $: 1 \quad \ldots .: 1 \ldots \quad$. . . .: 1. 1 1. 1 : : 1 :

758 SKRSPQKSPKKRQRVRQPASNSGSPIISTPRRSTASSVNATPSSARRILRFQDDEQNAGEDDND IMSPLPADEEAELQRRLQLGLRVSPRRRELHAPEE 857

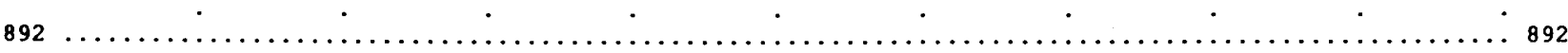

858 GSSGPLTEVGTPRLPNVSSAGQDDEQQQSVISFDNVEPGTISTGRLSLISGI IARLMQTE IFEEESYPVASLFERINEELPEEEKFSAQEYLAGLK IMSD 957

$892 \quad \ldots \ldots \ldots \ldots+892$

958 RNNLMVADDKVWRVZ 972

Figure 3. Comparison of the amino acid sequences of the $\mathrm{Mcm} 2$ and $\mathrm{Mcm} 3$ proteins. The $\mathrm{Mcm} 2$ sequence (upper) and the $\mathrm{Mcm} 3$ sequence (lower) were aligned using the GAP program of the UWGCG package with the gap weight and length weight set at 5.0 and 0.3 , respectively. The zinc-finger motif of $\mathrm{Mcm} 2$ is indicated by the boxed region. 
Mcm3 sequences (Figs. 3 and 4). These two proteins showed $50 \%$ similariry and $30 \%$ identity over their entire lengths by the gap program of GCG version 6.1 (Devereux et al. 1984), using a gap weight of 5.0 and length weight of 0.3 . The homology concentrates in three regions (Fig. 4): a 200-amino acid stretch from position 493 to 692 in $\mathrm{Mcm} 2$ (region II), and two short stretches, amino-terminal (region I) and carboxy-terminal (region III) to region II. Recently, when we submitted these sequences to the protein sequence bank of Dr. Mark Goebl, homologies to three additional proteins, Cdc46 from $S$. cerevisiae (K. Hennessy et al., this issue), and Cdc2l (A. Coxon and S. Kearsey, pers. comm.) and Nda4 (M. Yanagida, pers. comm.) from Schizosaccharomyces pombe were identified. Although $\mathrm{Cdc} 46$ and $\mathrm{Nda} 4$ are clearly homologs, showing $>70 \%$ identity (Hennessy et al., this issue), the pairwise similarities between $\mathrm{Mcm} 2, \mathrm{Mcm} 3$, $\mathrm{Cdc} 21$, and $\mathrm{Cdc} 46 / \mathrm{Nda} 4$ are about the same. The phenotypes associated with mutants defective in each of these genes suggest that they are involved in DNA synthesis at the beginning of $\mathrm{S}$ phase (Nasmyth and Nurse 1981; Hennessy et al. 1990).

Mcm2 contains a zinc-finger motif that is not conserved in $\mathrm{Mcm} 3$

Inspection of the Mcm2 ORF for sequence motifs asso- ciated with known functions revealed a zinc-finger motif ${ }_{342}$ Cys- $X_{2}$-Cys- $X_{19}$-Cys- $X_{2}$-Cys ${ }_{368}$ (Fig. 3, boxed region) characteristic of DNA-binding domains (Evans and Hollenberg 1988). The Phe, located 2 amino acids upstream from the zinc-finger motif, is a further indication that this motif is likely to function as a DNA-binding zinc finger as it is present at the same position upstream of a number of zinc-finger proteins (Berg 1990). We noted that this zinc-finger motif is not conserved in $\mathrm{Mcm} 3$, Cdc46/Nda4, or Cdc21.

To investigate the functional significance of the zincfinger motif of the $\mathrm{Mcm} 2$ protein, we changed the second cysteine pair by site-directed mutagenesis. Each cysteine was changed to one of three different amino acids (Tyr, Phe, and Ser) or both cysteines were changed to His (Fig. $5 \mathrm{a}$; Table 2). In this way, the new mcm 2 mutant alleles, mcm2-2 to $m c m 2-8$, were created. The mutant $(\mathrm{mcm} 2-1$ to $m c m 2-8)$ and wild-type genes were cloned into vector pSE355 (TRP1 ARS1 CEN4) to form plasmids pHY1pHY9. The resulting plasmids were transformed into HY101d ( $\mathrm{mcm} 2:$ :LEU2) carrying the resident plasmid pHY10 (MCM2 URA3) that provides the essential $\mathrm{Mcm} 2$ function for HY101d. Transformants were streaked onto FOA plates, and their growth at $15,23,30$, and $37^{\circ} \mathrm{C}$ in the absence of the resident pHY10 plasmid were examined. Transformants of pHY9 (MCM2) and pHY1 ( $\mathrm{mcm} 2$ 1) were able to grow on 5-fluoro-orotic acid (FOA) plates
Figure 4. A dot plot comparing the $\mathrm{Mcm} 2$ and $\mathrm{Mcm} 3$ sequences using the program COMPARE of the UWGCG package with a window size of 15 and stringency of 11.

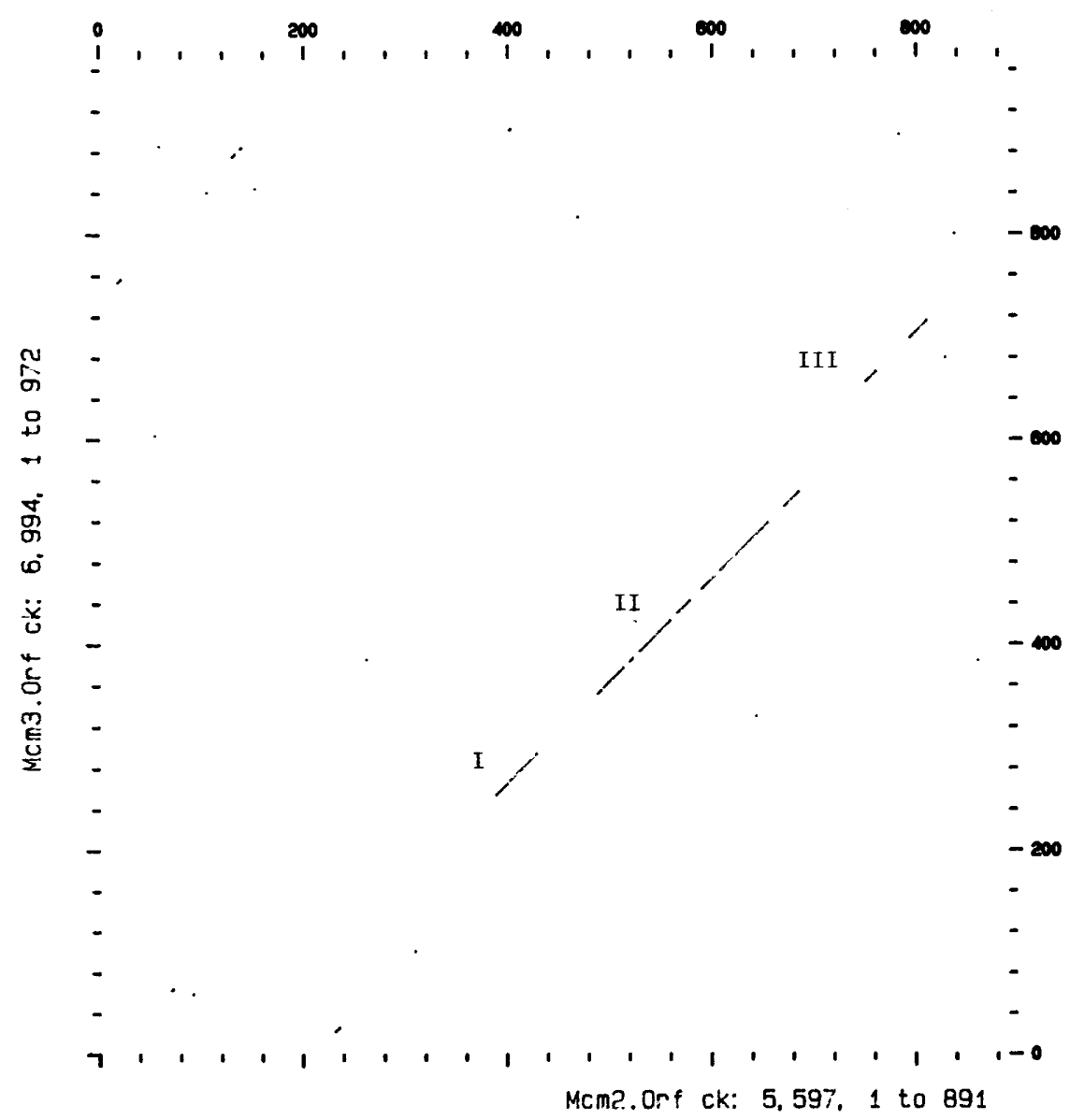




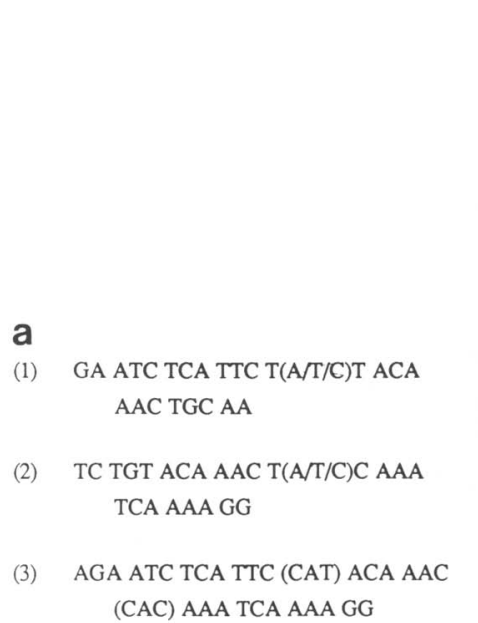

b

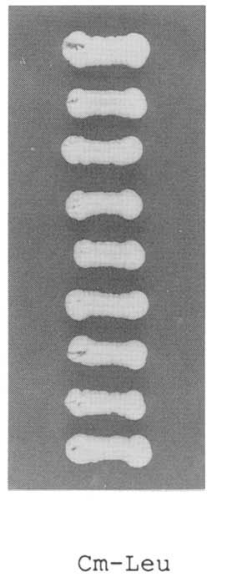

MCM2

mcm 2-1

$m c m 2-2$

$\mathrm{mcm} 2-3$

$m c m 2-4$

mcm $2-5$

$\mathrm{mcm} 2-6$

mcm2-7

mcm2-8

at all temperatures tested, although transformants of pHY1 showed a smaller colony size than those of pHY9. However, none of the transformants of $\mathrm{pHY} 2-8$ grew on FOA plates at any of the temperatures tested, suggesting that both residues of the second cysteine pair in the zincfinger motif of $\mathrm{Mcm} 2$ are crucial to the function of Mcm2 (Fig. 5b). Notably, histidine substitutions at these positions are equally deleterious for $\mathrm{Mcm} 2$ function.

The mcm2-1 mutation results in a Glu to Lys substitution 25 amino acids downstream of the putative zinc finger

To gain some insight into the structure-function relationship of the $\mathrm{Mcm} 2$ protein, we identified the nature of the mcm2-1 mutation. The approximate location of the mcm2-1 mutation was first determined by a series of targeted recombination events (Fig. 6a; Shortle et al. 1984). We constructed three plasmids, each containing a fragment of the MCM2 gene such that one end extends beyond the MCM2 gene and the other end lies within the MCM2 gene (Fig. 6b). The plasmids were cut with the appropriate restriction enzymes and transformed into an mcm2-1 strain (M46-1-3c). Targeted integration of a plasmid results in a duplication, but only one of the repeats has the entire MCM2 gene. Recovery of wild-type trans-

Table 2. Mutations obtained

\begin{tabular}{lccc}
\hline Mutation & Codon & Position & Amino acid \\
\hline$m c m 2-2$ & TAC & 368 & Tyr \\
mcm2-3 & TCC & 368 & Ser \\
mcm2-4 & TTC & 368 & Phe \\
mcm2-5 & TTT & 366 & Phe \\
mcm2-6 & TAT & 366 & Tyr \\
mcm2-7 & TCT & 366 & Ser \\
$m c m 2-8$ & CAT & 366 & His \\
& CAC & 368 & His \\
\hline
\end{tabular}

formants indicates that the mcm2-1 mutation must lie between the restriction enzyme cleavage site and the intact end of the MCM2 gene. Conversely, if only mutant transformants are recovered, then the mcm2-1 mutation must lie within the other half of the MCM2 gene.

The result of this experiment is shown in Figure 6b. Plasmids containing the large $\mathrm{XbaI}$ fragment (pMCM2.X1) digested by MluI only gave rise to mutant transformants, indicating that the mutation is to the right of the MluI site. In contrast, plasmids containing the BglII (pMCM2.Bg) or XbaI (pMCM2.X1) fragment cleaved with ClaI consistently generated $\$ 50 \%$ wild-type transformants, indicating that the mutation is to the left of the ClaI site. The generation of only $\sim 50 \%$ wild-type transformants may be due to nuclease degradation from the cleaved site, which would result in a gapped region that could only be repaired from the chromosomal copy. In this way, we were able to localize the mcm2-1 mutation to the region between the MluI and ClaI sites on the $5^{\prime}$ half of the MCM2 gene.

Plasmids containing the wild-type and $m c m 2-1$ alleles were recovered from a wild-type transformant derived from the ClaI-digested pMCM2.Bg plasmid. Briefly, genomic DNA was isolated, cleaved with SstI or HindIII, self-ligated, and transformed into $E$. coli. Plasmids generated from the SstI digestion contain the $m c m 2-1$ allele, whereas plasmids generated from the HindIII digestion contain the wild-type MCM2 allele (Fig. 6a). Isogenic plasmids containing the wild-type and mutant MCM2 genes were constructed by substituting the MluI-ClaI fragment from the wild-type MCM2 gene with that from the mutant. The identities of these alleles were confirmed by their $\mathrm{mcm}$ and growth phenotypes. When the MluI-ClaI fragments were sequenced, we found a single base difference between the mutant and the wild-type fragments. This $\mathrm{G} \rightarrow \mathrm{A}$ transition mutation, which resulted in a Glu $\rightarrow$ Lys substitution, is therefore responsible for both the $\mathrm{mcm}$ and temperature-sensitive growth phenotype of $\mathrm{mcm} 2-1$ (Fig. 6c).

This Glu $\rightarrow$ Lys substitution mutation lies 25 amino 
Yan et al.

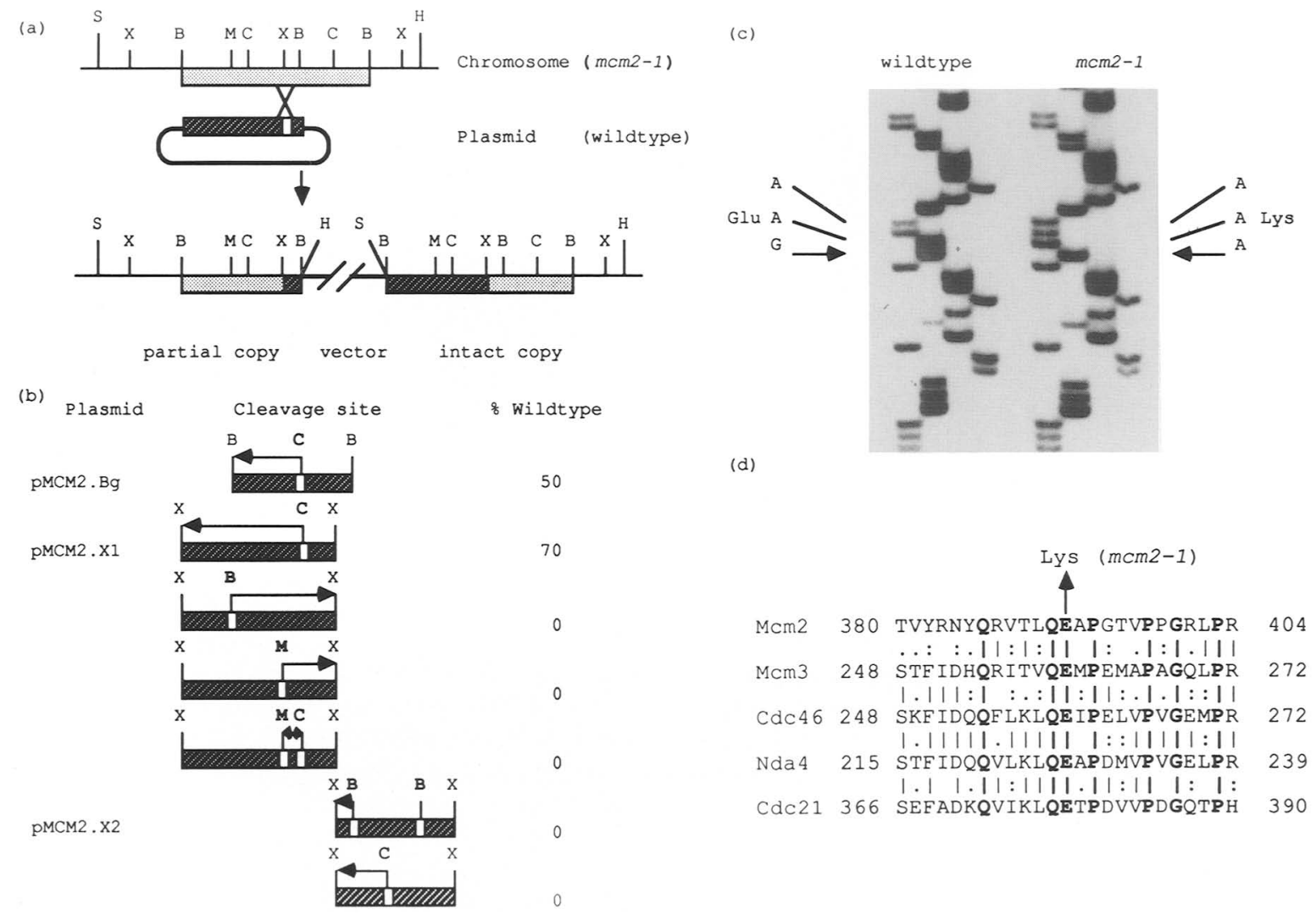

Figure 6. Identification of the mcm2-1 mutation. (a) Strategy for mapping the mcm2-1 mutation illustrated by using plasmid pMCM2.Bg cut with $\mathrm{XbaI}$. The integration results in an intact copy and a partial copy of the $M c m 2$ gene. $(b)$ The $m c m$ phenotype of the $\mathrm{mcm} 2-1$ strain transformed with different cleaved plasmids. Arrows indicate the location of the $\mathrm{mcm} 2-1$ mutation relative to the cleavage site. Wild-type and mutant transformants were distinguished by their growth rates at $37^{\circ} \mathrm{C}$. Twenty transformants from each transformation were checked. (B) BgIII; (C) CIaI; (H) HindIII; (M) MluI; (S) SstI; (X) XbaI. (c) Sequences of the wild-type and mutant DNAs in the region containing the $\mathrm{mcm} 2-1$ mutation. The single mutation predicts a substitution of lysine for glutamate at position 392. (d) Alignment of five homologous sequences in this region. Lines indicate identical amino acids. Dots and double dots indicate amino acids of different degrees of similarities. Residues in bold are invariant among all five proteins.

acids downstream of the zinc-finger motif. Interestingly, although the zinc-finger motif is not conserved in $\mathrm{Mcm} 3, \mathrm{Cdc} 21, \mathrm{Cdc} 46$, or $\mathrm{Nda} 4$, this region containing the mcm2-1 mutation is highly conserved in all five proteins (Fig. 6d). Of 25 amino acids, 7 are invariant in all five proteins. Similarities among all five proteins are obvious even in an expanded region of $\sim 50$ amino acids (Fig. 4, region I; K. Hennessy et al., this issue), with the greatest homology concentrated in the vicinity of the mom2-1 mutation.

\section{The $\mathrm{mcm} 2-1 \mathrm{mcm} 3-1$ double mutant is lethal}

The similarities in the protein sequences of $\mathrm{Mcm} 2$ and $\mathrm{Mcm} 3$ suggest that they might perform similar or related functions in the cell. If so, one might expect a double mutant of $\mathrm{mcm} 2-1 \mathrm{mcm} 3-1$ to have a more severe growth defect than either mutant alone. To determine the phenotype of the mcm2-1 mcm3-1 double mutant, we constructed a diploid strain that is $m \mathrm{~cm} 2-1$ homozygous and mcm3-1 heterozygous. Briefly, plasmid pMCM2-
1.S, which contains a fragment of the $m c m 2-1$ mutant gene, was cut with BglII and transformed into strain R614 (mcm3-1). The resultant transformants should contain a partial $m c m 2-1$ gene and the entire MCM2 gene. One such transformant was then crossed with the $m c m 2-1$ strain M46-8. The resulting diploid was grown in YEPD to saturation and plated on medium with FOA to select for the excision of the URA3 gene (Boeke et al. 1984). These excision events should yield an intact copy of either the wild-type or mutant allele of $M C M 2$, giving rise to diploids that are either heterozygous or homozygous for $m c m 2-1$ and that are distinguishable by their minichromosome maintenance phenotype.

The mcm2-1 homozygous, mcm3-1 heterozygous diploid was sporulated, and the resultant tetrads were dissected (Fig. 7a). Of 35 tetrads dissected, 29 yielded two live and two dead spores, 4 yielded one live spore, and the other 2 yielded no live spores. This result suggests that the $m c m 2-1 m c m 3-1$ double mutant is lethal, although neither mutation alone causes a discernible growth defect at the temperature $\left(23^{\circ} \mathrm{C}\right)$ used for spore 
a
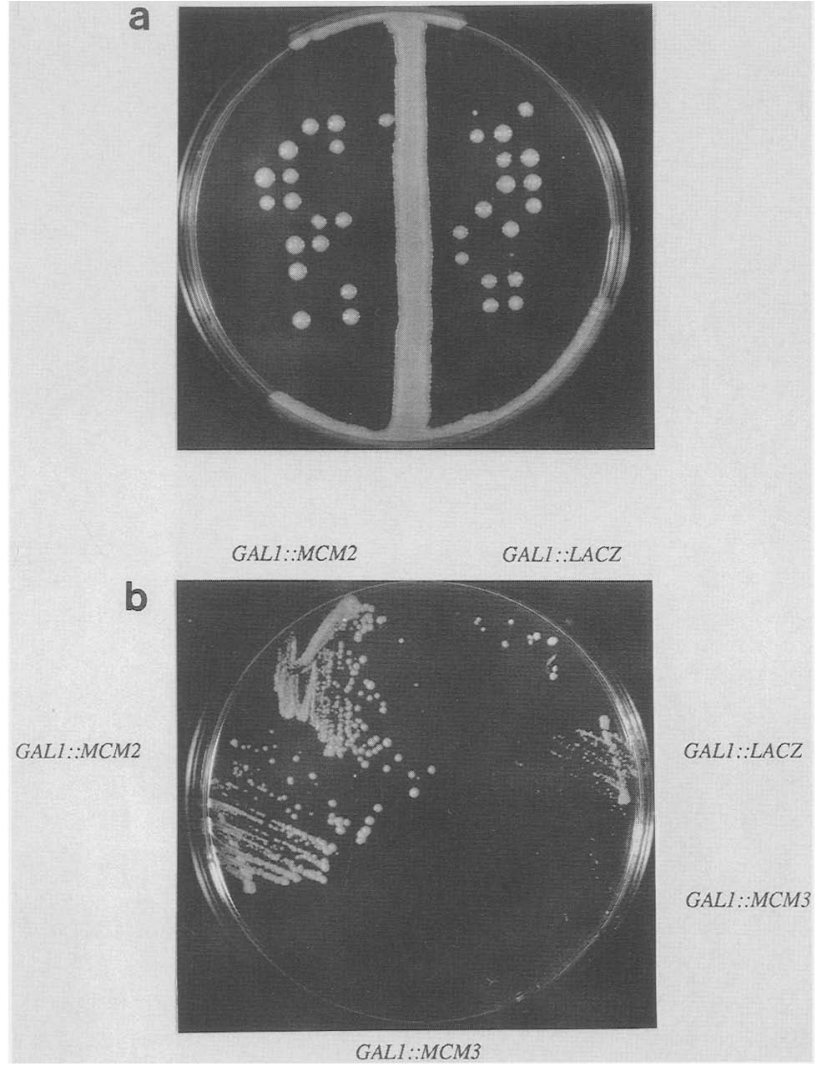

Figure 7. (a) The $m c m 2-1 \mathrm{mcm} 3-1$ double mutant is lethal. A diploid strain that is $m c m 2-1$ homozygous and $m c m 3-1$ heterozygous was sporulated, and the tetrads were dissected on YEPD plates at $23^{\circ} \mathrm{C}$. (b) Overproduction of the $\mathrm{Mcm} 3$ protein in mcm2-1 cells is lethal at $37^{\circ} \mathrm{C}$. Strain HY101d (mcm2::LEU2) containing plasmid pHY1 (mcm2-1 TRP1) was used as the host. Transformants carrying different overproducing plasmids were streaked onto $\mathrm{Cm}$-Ura galactose plates and allowed to grow at $37^{\circ} \mathrm{C}$ for 5 days.

germination. To ensure that the original FOA-resistant diploid did not result from the loss of the chromosome that carries the integrated plasmid, a scenario that would give the same result in tetrad analysis, a minichromosome containing MCM2 URA3 was transformed into the same diploid. In this strain, of 10 tetrads dissected, 1 yielded four live spores and 2 yielded three live spores. The mcm3-1 mutation always segregated with the minichromosome (MCM2 URA3) in the viable spores. These $m c m 3-1$ strains were then examined for their ability to grow independently of the plasmid on FOA plates. All of them failed to grow, leading us to conclude that the $\mathrm{mcm} 2-1 \mathrm{mcm} 3-1$ double mutant is inviable.

\section{Overproduction of $\mathrm{Mcm} 3$ is lethal in the $\mathrm{mcm} 2-1$ strain}

We have reported previously that overproduction of $\mathrm{Mcm} 3$ in a wild-type strain causes an ARS-specific minichromosome maintenance defect (Gibson et al. 1990). An Mcm3-overproducing strain containing pB620.MCM3 was constructed by placing the $M C M 3$ gene under the control of the GAL1 promoter in a $2 \mu$ vector, $\mathrm{pB} 620$. The stabilities of minichromosomes YCp121 (ARS121 LEU2) and YCp131 (ARS131 LEU2) in this strain, growing in either glucose or galactose medium, were measured by the rate of plasmid loss per cell per generation. As shown in Table 3, overproduction of $\mathrm{Mcm} 3$ has little effect on the stability of YCp121, which has a loss rate of 0.02 in glucose and 0.03 in galactose medium. However, overproduction of $\mathrm{Mcm} 3$ has a dramatic effect on the stability of YCp131, which has a loss rate of 0.03 in glucose and 0.25 in galactose medium. In contrast, there is no change in the rates of loss of these plasmids in glucose or galactose medium in the yeast strain containing $\mathrm{pB} 620 . \mathrm{MCM} 2$ and $\mathrm{pB} 704$, which are similar to pB620.MCM3, except that in these plasmids either $M C M 2$ or lacZ is fused to the GAL1 promoter instead of MCM3.

The lethality of the mcm2-1 mcm3-1 double mutant suggests that $\mathrm{Mcm} 2$ and $\mathrm{Mcm} 3$ may be involved in similar or related functions. Because overproduction of $\mathrm{Mcm} 3$ has an $\mathrm{Mcm}^{-}$phenotype similar to that of the mcm3-1 mutation, we were interested in the effect of overproduction of $\mathrm{Mcm} 3$ in the $\mathrm{mcm} 2-1$ mutant strain. Figure $7 \mathrm{~b}$ shows the effect of overproduction of $\mathrm{Mcm} 3$, $\mathrm{Mcm} 2$, and $\beta$-galactosidase in the $\mathrm{mcm} 2-1$ mutant strain at $37^{\circ} \mathrm{C}$. Overproduction of $\mathrm{Mcm} 2$, but not $\beta$-galactosidase, complements the slow growth phenotype of the mcm2-1 mutation. In contrast, overproduction of $\mathrm{Mcm} 3$ was lethal in the $m c m 2-1$ strain grown at $37^{\circ} \mathrm{C}$.

\section{Overproduction of Mcm2 partially complements the mcm3-1 mutation}

Overproduction of $\mathrm{Mcm} 3$ results in an $\mathrm{mcm}$ defect in the wild-type strain and a lethal phenotype in the $m c m 2-1$

Table 3. Effect of $\mathrm{Mcm} 2$ or $\mathrm{Mcm} 3$ overproduction on minichromosome stability

\begin{tabular}{lccc}
\hline $\begin{array}{l}\text { Overproducing } \\
\text { plasmid }\end{array}$ & $\begin{array}{c}\text { Test } \\
\text { plasmid }\end{array}$ & $\begin{array}{c}\text { Loss rate } \\
\text { in glucose }\end{array}$ & $\begin{array}{c}\text { Loss rate } \\
\text { in galactose }\end{array}$ \\
\hline pB620.MCM2 & YCp121 & 0.02 & 0.07 \\
pB620.MCM3 & YCp131 & 0.06 & 0.04 \\
& YCp121 & 0.02 & 0.03 \\
pB704 & YCp131 & 0.03 & 0.25 \\
& YCp121 & 0.07 & 0.05 \\
& YCp131 & 0.04 & 0.05 \\
\hline
\end{tabular}

Yeast strain $8534-8 \mathrm{C}$ was transformed with one of the overproducing plasmids (pB620.MCM2, pB620.MCM3, or pB704) to uracil prototrophy and one of the test plasmids (YCp121 or YCp131) to leucine prototrophy. The transformed cells were grown in complete medium lacking leucine and uracil, containing $3 \%$ glycerol and $2 \%$ ethanol as the carbon sources. They were then grown for an additional 10 generations in Cm-Ura medium with either $2 \%$ galactose or $2 \%$ glucose as the carbon source. Cells were first plated on Cm-Ura and then replicaplated on Cm-Leu-Ura. Loss rate is defined as plasmid loss per cell per generation. Numbers are averages of results from two to three independent experiments. 
strain. In contrast, overproduction of $\mathrm{Mcm} 2$ has no effect on minichromosome maintenance in the wild-type strain (see Table 3). Furthermore, overproduction of $\mathrm{Mcm} 2$ complements the temperature-sensitive growth defect of the mcm3-1 mutant (Fig. 8). However, this complementation is only partial as colonies resulting from $\mathrm{Mcm} 2$ overproduction are smaller than those resulting from $\mathrm{Mcm} 3$ overproduction. Also, this partial complementation is only observed when $\mathrm{Mcm} 2$ is overproduced (cells grown in galactose medium) but not when $\mathrm{Mcm} 2$ is produced at low levels /cells grown in glucose medium). Overproduction of $\beta$-galactosidase had no effect on the growth defect of the mcm3-1 strain.

The $\mathrm{mcm} 2-1$ and $\mathrm{mcm} 3-1$ mutants have different ARS specificities

The structural similarity and functional relationship between the $\mathrm{Mcm} 2$ and $\mathrm{Mcm} 3$ proteins suggest that these two proteins perform interacting or complementing functions. To gain further insight into their respective roles in ARS function, we felt that a direct comparison of

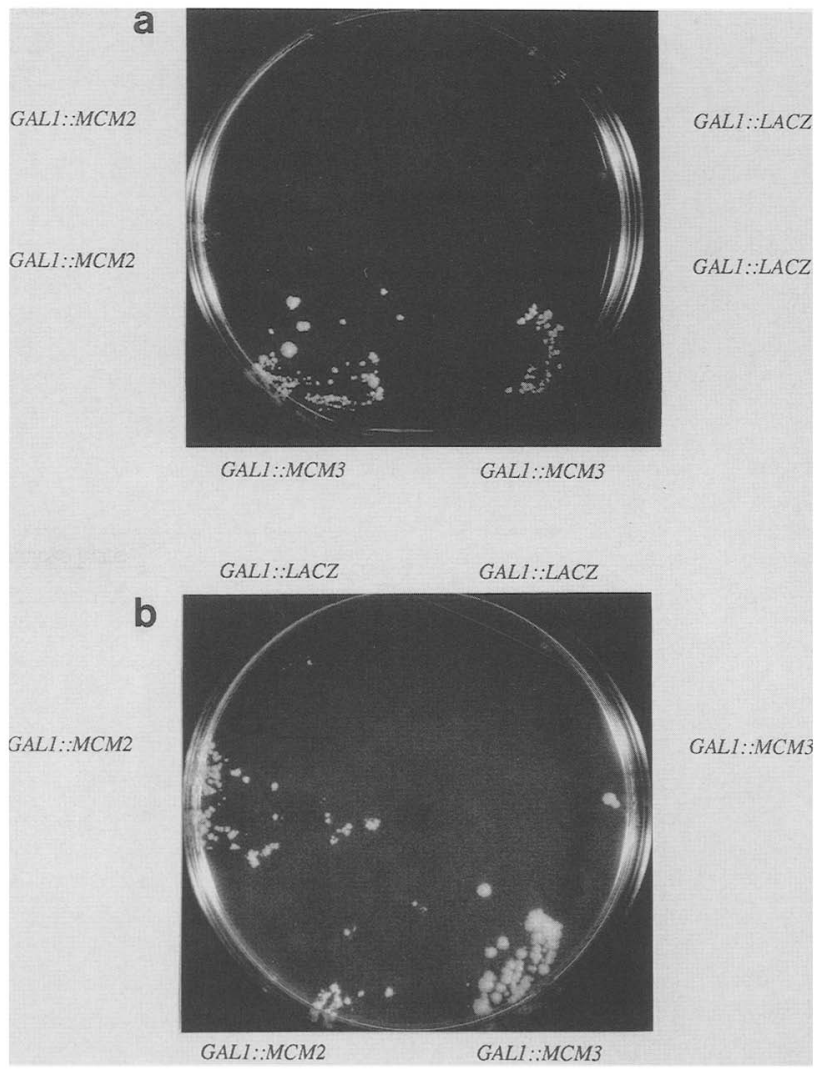

Figure 8. Overproduction of $\mathrm{Mcm} 2$ can partially complement mcm3-1. Overproducing plasmids were transformed into R61.4 ( $\mathrm{mcm} 3-1)$ strain. The transformants were streaked onto either $\mathrm{Cm}$-Ura glucose $(a)$ or Cm-Ura galactose plates $(b)$ and allowed to grow at $23^{\circ} \mathrm{C}$ for $6 \mathrm{hr}$ and then at $37^{\circ} \mathrm{C}$ for 5 days.

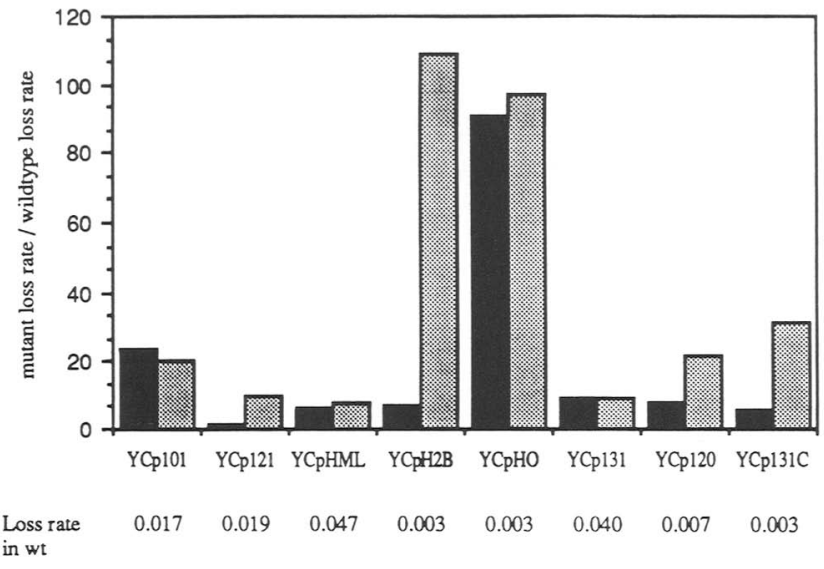

Figure 9. The effect of $m c m 2-1$ and $m c m 3-1$ mutations on minichromosome maintenance. The loss rates of minichromosomes carrying different ARSs in strains $8534-8 \mathrm{C}$ (wild type), M46-1-3C ( $\mathrm{mcm} 2-1$ ), and R61.4 (mcm3-1) are shown. Absolute loss rates in $8534-8 \mathrm{C}$ are presented in numbers, and the ratios of loss rates in mutants over those in $8534-8 \mathrm{C}$ are presented in a bar graph. (Solid box) mcm2-1; (stippled box) mcm3-1.

their ARS specificities in minichromosome maintenance might be informative.

We further defined ARS specificity in minichromosome maintenance in the $\mathrm{mcm}$ mutants by using a larger sample of well-characterized ARSs. ARS1, ARSHML, $A R S H 2 B$, and $A R S H O$ are ARS elements associated, respectively, with the TRP1 (Struhl et al. 1979), the silent mating-type locus $H M L \alpha$ (Feldman et al. 1984), the histone $H 2 B$ (Osley and Hereford 1982), and the endonuclease $H O$ (Kearsey 1984) genes. ARS131, ARS131C, and $A R S 120$ are three ARSs associated with subtelomeric $\mathrm{X}$ sequences (Chan and Tye 1983). ARS121 is a single-copy ARS element of unknown genomic location (Chan and Tye 1980). The loss rates of eight minichromosomes, each carrying CEN5 and one of these ARS elements, were measured in wild-type and mutant strains at room temperature. To compare the effects of each mutation on a particular minichromosome, the relative loss rates of each minichromosome in mutant and wild type are presented in a bar graph in Figure 9.

In the wild-type strain, all minichromosomes are stable, although to varying degrees. Four of them, YCpHO, YCpH2B, YCp120, and YCp131C, are extremely stable, with respective loss rates of $0.003,0.003,0.007$, and $0.003 /$ cell per generation. In contrast, YCp131 and YCpHML are lost at rates of 0.04 and $0.05 /$ cell per generation, $\sim 10$-fold higher than the group above. Minichromosomes YCp101 and YCp121 have intermediate loss rates of $\sim 0.02 /$ cell per generation (Fig. 9). A hierarchy for ARSs based on plasmid stabilities in the wild-type strain is, in descending order, ARSHO, ARSH2B, ARS131C, $A R S 120>A R S 1, A R S 121>A R S 131$, and ARSHML.

We then examined the effect of the $m c m 2-1$ mutation on the stability of these minichromosomes. We found that there is no correlation between the hierarchy of ARSs in wild-type cells and the stabilities of these ARSs 
in $m c m 2-1$ cells. For example, YCpHO and YCpH2B are comparable in stability in the wild-type strain. In the mutant, $\mathrm{YCpH} 2 \mathrm{~B}$ is also quite stable 17 -fold increase in loss rate over that in the wild-type), yet $\mathrm{YCpHO}$ has a 90-fold increase in loss rate in the mcm2-1 mutant. Similar observations are also made in the $m c m 3-1$ mutant, suggesting that the $\mathrm{mcm}$ phenotype of these mutants is not due to an amplification of preexisting differences in ARSs as a result of indirect effects, such as slower growth rates or changes in the length of the phases in the cell cycle.

A comparison of the effects of the $m \mathrm{~cm} 2-1$ and $\mathrm{mcm} 3$ 1 mutations on minichromosome stabilities reveals that these two mutations can exert quite different effects on the same ARS. For example, YCpH2B, which is among the most stable in wild-type strains, is little affected in mcm 2-1 (7-fold increase in loss rate) but becomes very unstable in mcm3-1 (110-fold increase in loss rate). Thus, two conclusions can be drawn from this study. First, there is no correlation between the relative strengths of the ARSs in wild-type and $\mathrm{mcm}$ mutant strains. Second, $m c m 2-1$ and $m c m 3-1$ mutants exert their most dramatic effects on different sets of ARSs.

\section{Discussion}

\section{Structural relationship between $\mathrm{Mcm} 2$ and $\mathrm{Mcm} 3$}

We used minichromosome maintenance as an assay to screen for mutants that affect the function of ARSs. We chose to study $m c m 1, m c m 2$, and $m c m 3$ because their ARS-dependent minichromosome maintenance defect suggests that they play important roles in the function of ARSs. These mutants also share other phenotypes characteristic of DNA replication defects, such as a premitotic cell cycle arrest with cells containing almost fully replicated DNA, increased chromosome loss, and hyperrecombination (Gibson et al. 1990).

Although the mutant phenotypes of $\mathrm{mcm} 1, \mathrm{mcm} 2$, and $m c m 3$ are remarkably similar, structural similarity is only shared between $\mathrm{Mcm} 2$ and $\mathrm{Mcm} 3$. While $\mathrm{Mcm} 1$ is a relatively small protein (286 amino acids), $M \mathrm{~cm} 2$ and $\mathrm{Mcm} 3$ are larger proteins of 890 and 971 amino acids, respectively. Extensive homology between the $\mathrm{Mcm} 2$ and $\mathrm{Mcm} 3$ proteins is localized in three regions (I, II, and III), with the most extensive and best homology found within the 200 amino acids of region II.

Inspection of the $\mathrm{Mcm} 2 \mathrm{ORF}$ revealed that, of nine cysteines in the entire ORF, four are spaced so that they could form a zinc finger similar to those found in certain DNA-binding proteins (Evans and Hollenberg 1988). Three types of zinc-finger motifs, Cys2/His2, Cys5-6, and Cys4, have been described. The zinc-finger motif of Mcm2 is of the Cys4 type. The Cys2/His2 and Cys5-6 zinc fingers have been demonstrated to be functional DNA-binding domains (Berg 1990). Proteins known to contain the Cys4 zinc-finger motifs include the adenovirus protein E1A (Flint and Shenk 1989), the yeast protein HOP1 (Hollingsworth et al. 1990), and eIF2 $\beta$ (Donahue et al. 1988); all three proteins are implicated in roles involving DNA or RNA binding. Mutagenesis of the cysteines or the amino acids around them in the zinc-finger motifs either abolished or modified the functions of these proteins. Furthermore, the zinc-finger motif of ElA has been shown to bind zinc (Culp et al. 1988) and constitutes at least part of the DNA-binding domain (Chatterjee et al. 1988). We have mutagenized the second cysteine pair in the putative zinc finger of $\mathrm{Mcm} 2$ and found these mutations to be lethal, suggesting that these cysteines are essential for the function of $\mathrm{Mcm} 2$.

We have also identified the mcm2-1 mutation to be a single-base-change mutation that converts a Glu to a Lys, 25 amino acids downstream of the putative zincfinger motif. The regions carboxyl to zinc fingers have been shown to be important for DNA binding (Pfeifer et al. 1989). Thus, Mcm2 may act by binding to DNA through its zinc-finger motif, a property expected of $\mathrm{Mcm} 2$ if it were directly involved in DNA replication at ARSs. Interestingly, although the zinc-finger motif is not conserved in $\mathrm{Mcm} 3$, the $\mathrm{mcm} 2-1$ mutation lies within one of the $\mathrm{Mcm} 2-\mathrm{Mcm} 3$ conserved regions, region I, suggesting that this region may also be important for $\mathrm{Mcm} 3$ function.

\section{Functional relationship between $M c m 2$ and $M c m 3$}

Although the ARS-specific minichromosome maintenance phenotype of $m c m 2-1$ and $m c m 3-1$ suggests that these two gene products are involved in the initiation of DNA replication at ARSs, cells depleted of or altered in the MCM2 or MCM3 gene products arrest with extensively replicated DNA (Gibson et al. 1990). We believe that this arrest phenotype is the result of selective initiation of DNA replication at only a small number of ARSs under conditions of limiting $\mathrm{Mcm} 2$ or $\mathrm{Mcm} 3$ activity. Although DNA synthesis can occur under these conditions, replication cannot be completed.

Further genetic analysis suggests that $\mathrm{Mcm} 2$ and Mcm3 may play some complementary functions in DNA replication. At room temperature, single mutants of $m c m 2-1$ or $m c m 3-1$ are viable, yet the double mutant is lethal. Moreover, overproduction of $\mathrm{Mcm} 2$ partially complements the mcm3-1 mutation. However, it is clear that these two proteins cannot completely substitute for each other as each of them is required for viability. There is some evidence suggesting that $\mathrm{Mcm} 2$ and $\mathrm{Mcm} 3$ may interact as components of a larger complex because overproduction of $\mathrm{Mcm} 3$ in the $m \mathrm{~cm} 2-1$ strain exacerbates the $m c m 2$ defect. The fact that the $m c m 2-1$ and $m c m 3-1$ mutations exert their most dramatic effects on different sets of ARSs suggests that if $\mathrm{Mcm} 2$ and $\mathrm{Mcm} 3$ do function in a complex by binding to ARSs, they both contribute to the binding specificity of the complex as a whole.

\section{Models for action of $\mathrm{Mcm} 2$ and $\mathrm{Mcm} 3$}

One of the most interesting features of the $\mathrm{mcm}$ mutants is the ARS specificity of the minichromosome maintenance defect. We examined the effects of the $m c m 2-1$ 
and $m c m$ 3-1 mutations on a large number of well-characterized ARSs. At low temperatures, both mutants affect different ARSs to greater or lesser degrees. At less permissive temperatures, all ARSs tested are affected in these mutants. Thus, it is unlikely that the gene products of MCM2 and MCM3 act only at a subset of ARSs. Rather, if they do act directly at ARSs, they both contribute to the activation of all ARSs, although each to different extents. It is also unlikely that this ARS specificity of the $\mathrm{mcm}$ mutants is simply an amplification of pre-existing differences inherent in ARSs, as strong ARSs in wild-type strains are not necessarily strong ARSs in the $\mathrm{mcm}$ mutants.

Given that $\mathrm{Mcm} 2$ and $\mathrm{Mcm} 3$ are structurally and functionally related, what might be their specific functions? We speculate that $\mathrm{Mcm} 2$ and $\mathrm{Mcm} 3$ are proteins directly involved in the activation of most, if not all, ARSs. A plausible model consistent with the data accumulated on $\mathrm{Mcm} 2$ and $\mathrm{Mcm} 3$ is that these two proteins interact in a multisubunit complex to act at ARSs. We suggest that both $\mathrm{Mcm} 2$ and $\mathrm{Mcm} 3$ contribute to the binding specificity of the complex as a whole, but contact of the complex with the DNA may be mediated by Mcm2. The mcm2-1 mutation could thus affect the binding affinity of $\mathrm{Mcm} 2$, whereas the $m \mathrm{~cm}$ 3-1 mutation could affect the interaction between $\mathrm{Mcm} 2$ and $\mathrm{Mcm} 3$. In this model overproduction of $\mathrm{Mcm} 3$ could lead to a stoichiometric imbalance of the complex, resulting in an $\mathrm{mcm}$ defect; on the other hand, overproduction of $\mathrm{Mcm} 2$ could increase the occupancy of the complex on the DNA. An equally plausible model is to suggest that $\mathrm{Mcm} 2$ and $\mathrm{Mcm} 3$ bind to ARSs independently of each other. In this case, the contribution of each of these proteins to ARS activity depends on the quantity and quality of the binding sites of these proteins at ARSs. This model explains the nonequivalent ARS specificity exhibited by the $m c m 2-1$ and $m c m 3-1 \mathrm{mu}-$ tants. Again, in this model, we have to invoke $\mathrm{Mcm} 3$ acting as a subunit in a complex to account for the $\mathrm{mcm}$ phenotype that results from overproduction of $\mathrm{Mcm} 3$.

\section{Mcm2 and Mcm3 as members of a larger family of proteins}

The finding that $\mathrm{Mcm} 2$ and $\mathrm{Mcm} 3$ are homologous to three other proteins, all of which play important roles at the beginning of $S$ phase, supports the idea that $\mathrm{Mcm} 2$ and $\mathrm{Mcm} 3$ are proteins involved in the initiation of DNA replication at ARSs. Sequence conservation between Mcm2, Mcm3, Cdc46/Nda4 (S. pombe), and Cdc21 (S. pombe) is remarkably strong. Each pair of sequences share $\sim 30 \%$ identity, with the best homologies localized in three regions. $\mathrm{Cdc} 46$ has been shown to be required for DNA synthesis. Interestingly, this protein is mobilized from the cytoplasm to the nucleus in a cellcycle-dependent manner, such that it appears in the nucleus as mitosis is completed and persists there until the next round of DNA synthesis is initiated (Hennessy et al. 1990). Although tight alleles of $c d c 46$ arrest at the $G_{1} / S$ phase with an unreplicated genome, leaky alleles of cdc46 mutants have an arrest phenotype similar to mcm2-1 and mcm3-1 mutants (K. Hennessy and D. Botstein, pers. comm.). Clearly, $\mathrm{Mcm} 2, \mathrm{Mcm} 3$, and Cdc46 belong to a family of proteins that are likely to serve related functions. Correlation between structure and function in the conserved domains of these proteins will provide information on the involvement of this family of proteins in the early events of DNA replication in yeast.

\section{Materials and methods}

Strains and plasmids

Yeast strains used are 8534-8C (MAT $\alpha$ ura3-52 leu2-3, -112

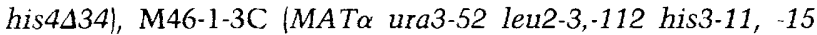
mcm2-1], tAM46-1-3C [M46-1-3C with one copy of the plasmid Y5-M-R-1 (mcm2::URA3) integrated at the $\mathrm{mcm} 2$ locus], TD4 (MATa ura3-52 leu2-3,-112 his4-519 trpl-289), MY4C/Y4

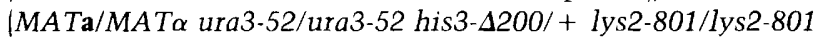
ade2-101/ade2-101 +/tyrl+/trp1 mcm2-1/+), 8534/R61 (MATa /MATa ura3-52/ura3-52 leu2-3,112/leu2-3,112 +/his3-11 his $4 \Delta 34 /+$ +/lys2 +/ade2 +/trp1), HY101d (MATa ura3-52 leu2-3,-112 his4-519 trp1-289 mcm2::LEU2), M46-8 (MATa mcm2-1 ura3-52 leu2-3,-112 his3 ade2 ade3), and R61-4 (MATa mcm3-1 ura3-52 leu2-3,-112 his4434).

E. coli $\mathrm{HB} 101$ (hsd20 recA13) was used for plasmid construction and preparation. E. coli JM101 $[\Delta($ lac-proAB) F'traD36pro$A B l a c I^{\circ} \Delta$ (lacZ)M15] was used for preparing single-stranded

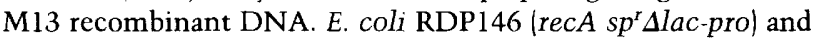
NS2114Sm (recA sm ${ }^{\mathrm{r}} \mathrm{A}$-cre prophage in chromosome) was used for shuttle mutagenesis (Seifert et al. 1986).

Plamids used in this study are listed in Table 4.

Media, chemicals, and enzymes.

Rich (YEPD) and complete $(\mathrm{Cm})$ media were prepared as described (Sherman et al. 1974). FOA plates were made according to Boeke et al. (1984). The T7 DNA polymerase sequencing kit was purchased from the United States Biochemical Co., Cleveland, $\mathrm{OH}$. The T4 DNA polymerase deletion kit was from International Biotechnologies, Inc., New Haven, CT. The Mutagene $\mathrm{Ml3}$ in vitro mutagenesis kit is the product of Bio-Rad Laboratories, Richmond, CA.

\section{Yeast genetic techniques and transformation}

Mating, sporulation, tetrad dissection, and other yeast genetic manipulations were carried out following the standard procedures described by Sherman et al. (1974). Mitotic plasmid stability assays and protein overproduction in yeast were carried out as described (Gibson 1989). Plasmid loss rate is determined by $1-(F / I)^{1} /^{N}$, where $I$ is the initial percentage of plasmid-containing cells and $F$ is the percentage of plasmid-containing cells after $N$ generations. Yeast cells were transformed using the lithium acetate method (Ito et al. 1983).

\section{Shuttle mutagenesis}

Shuttle mutagenesis using the mini-Tn 3 transposon has been described (Seifert et al. 1986). The cloned yeast DNA fragment containing the MCM2 gene was subcloned into vector pHHS6 and passaged through strain NS2114Sm, which carries a miniTn3 transposon with a URA3 gene. Plasmids containing insertions were isolated, and the insertion sites were mapped using restriction enzymes. Those plasmids with insertions at appro- 
Table 4. Plasmids used in this study

\begin{tabular}{|c|c|c|}
\hline Plasmid & Description & $\begin{array}{l}\text { Source/ } \\
\text { reference }\end{array}$ \\
\hline YCp50 library & yeast DNA bank in YCp50 (URA3 ARS1 CEN4) & Rose et al. (1987) \\
\hline YCp101 & LEU2 ARS1 CEN5 & this lab \\
\hline YIp56 & URA3-containing vector & K. Struhl \\
\hline YCp86 & URA3 ARS1 CEN3 & K. Struhl \\
\hline YCp121 & LEU2 ARS121 CEN5 & this lab \\
\hline YCpHML & URA3 ARSHML CEN5 & this study \\
\hline YCpH2B & URA3 LEU2 ARSH2B CEN5 & this lab \\
\hline $\mathrm{YCpHO}$ & URA3 LEU2 ARSHO CEN5 & this lab \\
\hline YCpl31 & LEU2 ARS131 CEN5 & this lab \\
\hline YCp120 & URA3 LEU2 ARS120 CEN5 & this lab \\
\hline pYES3 & URA3 ARS1 CEN5 & this lab \\
\hline pM46-33 & original MCM2 clone in YCp50 & this study \\
\hline Y5-M-R-1 & URA3, 4.5-kb EcoRI fragment of the yeast clone M46-33 & this study \\
\hline pHSS6 & kanamycin ${ }^{\mathrm{r}}$, ori & Seifert et al. (1986) \\
\hline pLB101 & chloramphenicol ${ }^{\mathrm{r}}, \operatorname{Tn} 3$ transposase & Seifert et al. (1986) \\
\hline pOX38:: m-Tn3 & ampicillin ${ }^{\mathrm{r}}, \operatorname{mini}-\mathrm{Tn} 3(U R A 3 L A C Z)$ & Seifert et al. (1986) \\
\hline pHSS6.M46 & PvuII fragment of M46-33 cloned into pHHS6 & this study \\
\hline pHSS.M46.n & pHSS6.M46 inserted by mini-Tn 3 & this study \\
\hline pHSS.M46.Leu & pHSS6.M46 inserted by mini-Tn3 (LEU2 $L A C Z)$ inside $M C M 2$ & this study \\
\hline pMCM2.X1 & 3.5-kb XbaI fragment of M46-33 (5' part of MCM2) on YIp56 & this study \\
\hline pMCM2.X2 & 1.8-kb XbaI fragment of M46-33 ( $3^{\prime}$ part of $M C M 2$ ) on YIp56 & this study \\
\hline pMCM2.Bg & 2.6-kb BglII fragment of M46-33 (5' part of MCM2) on YIp56 & this study \\
\hline pMCM2-1.S & SstI to BglII fragment with $\mathrm{mcm} 2-1$ & this study \\
\hline pSE355 & TRP1 ARS1 CEN3 & S. Elledge \\
\hline pHY1-n & pSE355 with $m c m 2-1$ to $m c m-2-8$ & this study \\
\hline pHY9 & pSE355 with MCM2 & this study \\
\hline pHY10 & MCM2 gene cloned into YCp86 & this study \\
\hline pHY12 & pSE355 with $G A L I:: M C M 2$ & this study \\
\hline pB620 & URA3 GAL1-UAS $2 \mu A R S$ & Goff et al. (1984) \\
\hline $\mathrm{pB} 620 . \mathrm{MCM} 2$ & URA3 GAL1::MCM2 $2 \mu A R S$ & this study \\
\hline $\mathrm{pB} 620 . \mathrm{MCM} 3$ & $U R A 3$ GAL1::MCM3 $2 \mu A R S$ & this lab \\
\hline $\mathrm{pB} 704$ & URA3 GAL1::LACZ $2 \mu A R S$ & Goff et al. $\{1984\}$ \\
\hline
\end{tabular}

priate positions were then transformed into the $m \mathrm{~cm} 2-1$ strain, M46-1-3C, and $\mathrm{Ura}^{+}$transformants were tested for temperature-sensitive growth.

\section{DAPI staining}

Staining of cells with the DNA-specific dye DAPI was carried out according to published procedures (Williamson and Fennell 1975).

\section{Flow cytometry}

Cells were stained with propidium iodide as published previously (Hutter and Eipel 1978), except that $0.25 \%$ Triton X-100 was added to the solutions and RNase A treatment was extended to $2.5 \mathrm{hr}$ with vigorous shaking at $37^{\circ} \mathrm{C}$. The analysis was performed on EPICS Profile.

\section{DNA sequencing}

DNA fragments of the MCM2 gene were cloned into $\mathrm{M} 13 \mathrm{mp} 18$ or 19 (Messing 1983). Progressive deletions were constructed by the method of Dale et al. (1985) using the T4 DNA polymerase kit from IBI. Sequences from both strands were determined by the dideoxynucleotide chain-termination method of Sanger et al. (1977) using the T7 Sequenase kit from U.S. Biochemical.
Computer analysis was performed using the program package from the University of Wisconsin Genetics Computer Group (Devereux et al. 1984).

\section{Site-specific mutagenesis}

Oligonucleotides used for mutagensis were synthesized at the Cornell Biotechnology Center. Mutagenesis was carried out using the protocol of Kunkel (Kunkel et al. 1987). Annealing of oligonucleotides and second-strand synthesis were carried out using the Bio-Rad Mutagene kit. Mutagenized clones were screened by direct sequencing. MluI-ClaI restriction fragments containing the mutations were substituted for the corresponding sequence of the wild-type MCM2 gene on plasmid $\mathrm{pHY} 9$.

\section{Acknowledgments}

We thank Kevin Hennessy, Mitsuhiro Yanagida, and Stephen Kearsey for communications of their unpublished data. We are grateful to Mark Goebl and Clarence Chan for identifying sequence homologies between $\mathrm{Mcm} 2, \mathrm{Mcm} 3, \mathrm{Cdc} 46 / \mathrm{Nda} 4$, and Cdc21. This work was supported by National Institutes of Health grant GM34190.

The publication costs of this article were defrayed in part by payment of page charges. This article must therefore be hereby 
marked "advertisement" in accordance with 18 USC section 1734 solely to indicate this fact.

\section{References}

Berg, J.M. 1990. Zinc finger domains: Hypotheses and current knowledge. Annu. Rev. Biophys. Biophys. Chem. 19: 405421.

Biswas, S.B. and E.E. Biswas. 1990. ARS binding factor I of the yeast Saccharomyces cerevisiae binds to sequences in telomeric and nontelomeric autonomously replicating sequences. Mol. Cell. Biol. 10: 810-815.

Boeke, J.D., F. LaCroute, and G. Fink. 1984. A positive selection for mutants lacking orotidine-5'-phosphate decarboxylase activity in yeast: 5-Fluoro-orotic acid resistance. Mol. Gen. Genet. 197: 345-346.

Bramhill, D. and A. Kornberg. 1988. A model for initiation at origins of DNA replication. Cell 54: 915-918.

Broach, J.R., Y.-Y. Li, J. Feldman, M. Jayaram, J. Abraham, K.A. Nasmyth, and J.B. Hicks. 1983. Localization and sequence analysis of yeast origins of DNA replication. Cold Spring Harbor Symp. Quant. Biol. 47: 1165-1173.

Chan, C.S.M. and B.-K. Tye. 1980. Autonomously replicating sequences in Saccharomyces cerevisiae. Proc. Natl. Acad. Sci. 77: 6329-6333.

- 1983. Organization of DNA sequences and replication origins at yeast telomeres. Cell 33: 563-573.

Chatteriee, P.K., M. Bruner, and S.J. Flint. 1988. DNA-binding properties of an adenovirus $289 \mathrm{R}$ ElA protein. EMBO $/ .7$ : 835-841.

Culp, J.S., L.C. Webster, D.J. Friedman, C.L. Smith, W.J. Huang, F.Y.-H. Wu, M. Rosenberg, and R.P. Ricciardi. 1988. The 289-amino acid E1A protein of adenovirus binds zinc in a region that is important for trans-activation. Proc. Natl. Acad. Sci. 85: 6450-6454.

Dale, R., B. McClure, and J. Houchins. 1985. A rapid singlestranded cloning strategy for producing a sequential series of overlapping clones for use in DNA sequencing: Application to sequencing the corn mitochondrial $18 \mathrm{~S}$ rDNA. Plasmid 13: $31-40$.

Devereux, J., P. Haeberli, and O. Smithies. 1984. A comprehensive set of sequence analysis programs for the VAX. Nucleic Acids Res. 12: 387-395.

Diffley, J.F.X. and B. Stillman. 1988. Purification of a yeast protein that binds to origins of DNA replication and a transcriptional silencer. Proc. Natl. Acad. Sci. 85: 2120-2124.

Donahue, T.F., A.M. Cigan, E.K. Pabich, and B.C. Valavicius. 1988. Mutations at a $\mathrm{Zn}$ (II) finger motif in the yeast eIF2 $\beta$ gene alter ribosomal start-site selection during the scanning process. Cell 54: 621-632.

Eisenberg, S., C. Civalier, and B.-K. Tye. 1988. Specific interaction between a Saccharomyces cerevisiae protein and a DNA element associated with certain autonomously replicating sequences. Proc. Nat1. Acad. Sci. 85: 743-746.

Evans, R.M. and S.M. Hollenberg. 1988. Zinc-fingers: Gilt by association. Cell 52: 1-3

Feldman, J.B., J.B. Hicks, and J.R. Broach. 1984. Identification of sites required for repression of a silent mating type locus in yeast. J. Mol. Biol. 178: 815-834.

Flint, J. and T. Shenk. 1989. Adenovirus E1A protein paradigm viral transactivator. Annu. Rev. Genet. 23: 141-161.

Gibson, S. 1989. "Analysis of $M C M 3$, a minichromosome maintenance mutant of yeast with a cell division cycle arrest phenotype." Ph.D thesis. Cornell University, Ithaca, New York.
Gibson, S., R. Surosky, P. Sinha, G. Maine, and B.-K Tye. 1987. Complexity of the enzyme system for the initiation of DNA replication in yeast. UCLA Symp. Mol. Cell. Biol. 47: 341354.

Gibson, S., R. Surosky, and B.-K. Tye. 1990. The phenotype of the minichromosome maintenance mutant $\mathrm{mcm} 3$ is characteristic of mutants defective in DNA replication. Mol. Cell. Biol. 10: 5707-5720.

Goff, C.G., D.T. Moir, T. Kohno, T.C. Gravnis, R.A. Smith, E. Yamasaki, and A. Taunton-Rigby. 1984. Expression of calf prochymosin in Saccharomyces cerevisiae. Gene 27: 35-46.

Hennessy, K.M., C. Clark-Adams, and D. Botstein. 1990. Subcellular localization of yeast CDC46 protein varies with the cell cycle. Genes \& Dev. 4: 2252-2263.

Hollingsworth, N.M., L. Goetsch, and B. Byers. 1990. The HOP1 gene encodes a meiosis-specific component of yeast chromosomes. Cell 61: 73-84.

Huberman, J.A., J. Zhu, L.R. Davis, and C.S. Newlon. 1988. Close association of a DNA replication origin and an ARS element on chromosome III of the yeast, Saccharomyces cerevisiae. Nucleic Acids Res. 16: 6373-6384.

Hutter, K.J., and H.E. Eipel. 1978. Flow cytometric determinations of cellular substances in algae, bacteria, molds and yeasts. Antonie Leeuwenhoek I. Microbiol. Serol. 44: 269282.

Ito, H., Y. Fukuda, K. Murata, and A. Kimura. 1983. Transformation of intact yeast cells treated with alkali cations. $J$. Bacteriol. 153: 163-168.

Kearsey, S. 1984. Structural requirements for the function of a yeast chromosomal replicator. Cell 37: 299-307.

Kunkel, T.A., J.D. Roberts, and R.A. Zakour. 1987. Rapid and efficient site-specific mutagenesis without phenotypic selection. Methods Enzymol. 154: 367-382.

Maine, G.T., P. Sinha, and B.-K.Tye. 1984. Mutants of S. cerevisiae defective in the maintenance of minichromosomes. Genetics 106: 365-385.

Messing, J. 1983. New M13 vectors for cloning. Methods Enzymol. 101: 20-78.

Nasmyth, K. and P. Nurse. 1981. Cell division cycle mutants altered in DNA replication and mitosis in the fission yeast Schizosaccharomyces pombe. Mol. Gen. Genet. 182: 119124.

Osley, M.A. and L. Hereford. 1982. Identification of a sequence responsible for periodic synthesis of yeast histone $2 \mathrm{~A}$ mRNA. Proc. Natl. Acad. Sci. 79: 7689-7693.

Passmore, S., G.T. Maine, R. Elble, C. Christ, and B.-K. Tye. 1988. Saccharomyces cerevisiae protein involved in plasmid maintenance is necessary for mating of MATa cells. J. Mol. Biol. 204: 593-606.

Passmore, S., R. Elble, and B.-K. Tye. 1989. A protein involved in minichromosome maintenance in yeast binds a transcriptional enhancer conserved in eukaryotes. Genes \& Dev. 3: 921-935.

Pfeifer, K., K.-S. Kim, S. Kogn, and L. Guarente. 1989. Functional dissection and sequence of yeast HAPl activator. Cell 56: 291-301.

Rose, M.D., P. Novick, J.H. Thomas, D. Botstein, and G.R. Fink. 1987. A Saccharomyces cerevisiae genomic plasmid bank based on a centromere-containing shuttle vector. Gene 60: 237-243.

Rothstein, R.J. 1983. One-step gene disruption in yeast. Methods Enzymol. 101: 202-211.

Sanger, F., S. Nicklen, and A.R. Coulson. 1977. DNA sequencing with chain-terminating inhibitors. Proc. Natl. Acad. Sci. 74: 5463-5467.

Seifert, H.S., E.Y. Chen, M. So, and F. Heffron. 1986. Shuttle 
mutagenesis: A method of transposon mutagenesis for Saccharomyces cerevisiae. Proc. Natl. Acad. Sci. 83: 735-739.

Sherman, F., G.R. Fink, and C.W. Lawrence. 1974. Methods in yeast genetics. Cold Spring Harbor Laboratory, Cold Spring Harbor, New York.

Shortle, D., P. Novick, and D. Botstein. 1984. Construction and genetic characterization of temperature-sensitive mutant alleles of the yeast actin gene. Proc. Natl. Acad. Sci. 81: 48894893.

Sinha, P., V. Chan, and B. Tye. 1986. A mutant that affects the function of autonomously replicating sequences in yeast. $J$. Mol. Biol. 192: 805-814.

Stillman, B. 1989. Initiation of eukaryotic DNA replication in vitro. Annu. Rev. Cell Biol. 5: 197-245.

Struhl, K., D.T. Stinchcomb, S. Scherer, and R.W. Davis. 1979. High-frequency transformation of yeast: Autonomous replication of hybrid molecules. Proc. Natl. Acad. Sci. 76: 10351039.

Umek, R.M. and D. Kowalski. 1988. The ease of DNA unwinding as a determinant of initiation at yeast replication origins. Cell 52: 559-567.

Walker, S.S., S.C. Francesconi, and S. Eisenberg. 1990. A DNA replication enhancer in Saccharomyces cerevisiae. Proc. Nat. Acad. Sci. 87: 4665-4669.

Williamson, D.H. and D.I. Fennell. 1975. The use of fluorescent DNA-binding agent for detecting and separating yeast mitochondrial DNA. Methods Cell Biol. 12: 335-351. 


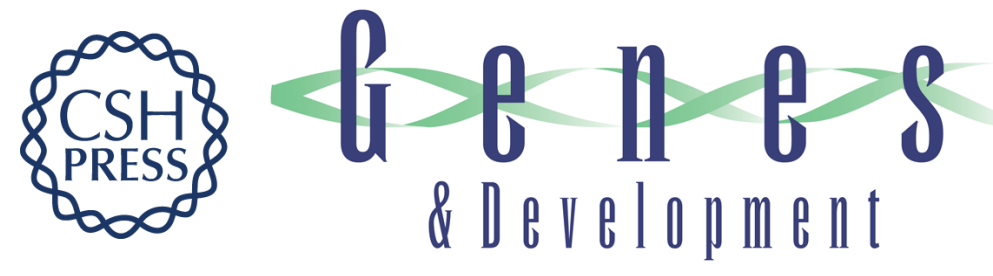

\section{Mcm2 and Mcm3, two proteins important for ARS activity, are related in structure and function.}

H Yan, S Gibson and B K Tye

Genes Dev. 1991, 5:

Access the most recent version at doi:10.1101/gad.5.6.944

References This article cites 45 articles, 17 of which can be accessed free at:

http://genesdev.cshlp.org/content/5/6/944.full.html\#ref-list-1

License

Email Alerting

Service

Receive free email alerts when new articles cite this article - sign up in the box at the top right corner of the article or click here.

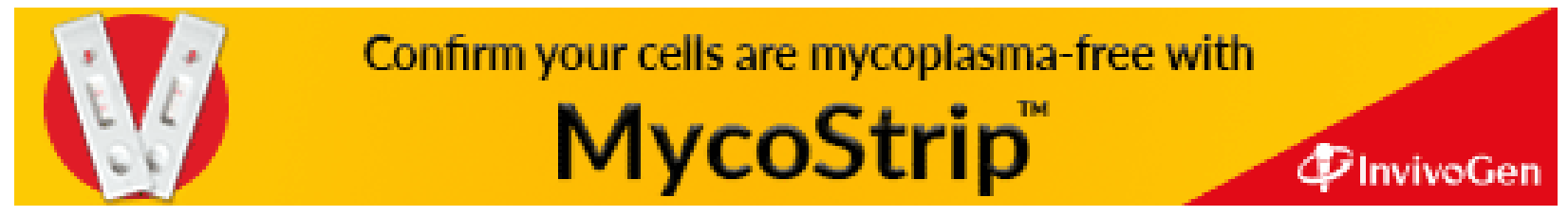

